\title{
Studies on Character Association and Path Coefficient Analysis for Yield Components in Blackgram (Vigna mungo (L). Hepper Genotypes
}

\author{
V. Sridhar ${ }^{1}$, B. V. Vara $\operatorname{Prasad}^{1}{ }^{*}$, D. Shivani ${ }^{1}$ and S. Srinivasa Rao $^{2}$ \\ ${ }^{1}$ Department of GPBR, College of Agriculture, PJTSAU, Rajendranagar, \\ Hyderabad-30, India \\ ${ }^{2}$ ARS, Madhira, PJTSAU, Khammam District, Telangana State, India \\ *Corresponding author
}

\begin{tabular}{|l|}
\hline Ke y w or d s \\
$\begin{array}{l}\text { Correlation, Path } \\
\text { analysis, Blackgram } \\
\text { genotypes }\end{array}$ \\
\hline Article Info \\
\hline $\begin{array}{l}\text { Accepted: } \\
\text { 15 December } 2019 \\
\text { Available Online: } \\
\text { 20 January 2020 }\end{array}$ \\
\hline \hline
\end{tabular}

A B S T R A C T

The experiment was conducted under rainfed condition at Agricultural Research Station, Madhira during early rabi 2016 using thirty five blackgram genotypes as materials with four released varieties viz., MBG207, LBG-752, PU-31 and IPU-2-43 as checks. Estimation of variation, phenotypic and genotypic correlations along with path analysis was calculated for the material under study. Days to maturity showed positive significant association with plant height, number of clusters per plant, number of pods per plant, 100 seed weight, seed yield per plant and seed yield (kg/ha). Seed yield per plant expressed highly significant and positive association with all traits studied. Path analysis showed that days to maturity, plant height and number of clusters per plant showed positive direct effect coupled with positive indirect effects through number of pods per plant and seed 100 seed weight on seed yield per plant resulting in positive significant correlation with seed yield ( $\mathrm{kg} / \mathrm{ha})$.

\section{Introduction}

Blackgram (Vigna mungo (L). Hepper, $2 \mathrm{n}=22$ ), known as urdbean, is an important grain legumes for its nutritional quality and the suitability to any cropping system. Blackgram has the potential of supplying a major portion of protein demand and restoring the soil health at the same time. Blackgram is the cheapest source of protein for the poor and has long been known as the poor men's meat. Pulses contain a remarkable amount of proteins, minerals, vitamins and carbohydrates. Among the various pulses, blackgram is an important one which contains approximately $25-28 \%$ protein, $4.5-5.5 \%$ ash, $0.5-1.5 \%$ oil, $3.5-4.5 \%$ fibre and $62-65 \%$ carbohydrate on dry weight basis (Kaul, 1982). The knowledge on interrelationship of plant characters with seed yield and among themselves is of paramount importance to the breeder for making importance in complex character like seed yield, for which direct selection is not much effective. Correlation 
measures the degree and direction of association between two or more variables. Path coefficient analysis is simply a standardized partial regression coefficient which splits the correlation coefficient into the measures of direct and indirect effects. In other words, it measures the direct and indirect contribution of various independent characters on a dependent character. The correlation and path coefficient analysis provide information about the relative importance of various yield components in the expression of yield and thus, help in formation of appropriate selection strategy.

\section{Materials and Methods}

The experiment was conducted in the experimental farm of Agricultural Research Station, Madhira during rabi 2016. Thirty five blackgram genotypes were taken as materials with four released varieties as checks, viz., MBG-207, LBG-752, PU-31 and IPU-243. Each row of $1 \mathrm{~m}$ length consists of 10 plants with a spacing of $10 \mathrm{~cm}$ between the plants and $30 \mathrm{~cm}$ between rows was maintained. The observations were recorded on days to $50 \%$ flowering, days to maturity, plant height $(\mathrm{cm})$, number of clusters per plant, number of pods per plant, 100 seed weight, seed yield per plant and seed yield $(\mathrm{kg} / \mathrm{ha})$. The statistical analysis and variance due to different sources was worked out according to Panse and Sukhatme (1967), genotypic correlation (Al Jibouri et al., 1958) and path coefficient analysis (Dewey and Lu, 1959).

\section{Results and Discussion}

Analysis of variance suggested considerable amount of variability in the material under study. The list of genotypes included in the present study is shown in Table 1. The genotypic correlations coefficients between seed yield and its component characters and inter correlation among different traits are presented in Table 2. Days to 50\% flowering showed positive significant association with days to maturity. Days to maturity showed positive significant association with plant height, number of clusters per plant, number of pods per plant, 100 seed weight, seed yield per plant and seed yield ( $\mathrm{kg} / \mathrm{ha})$. Plant height showed positive significant association with all other traits studied (Fig 1). The remaining traits viz., number of clusters per plant, number of pods per plant, 100 seed weight and seed yield per plant showed positive significant correlation with seed yield (kg/ha). Seed yield per plant expressed highly significant and positive association with all traits studied. This result was in close agreement with those obtained by earlier workers viz., Nagarjuna Sagar and Reddy Sekhar (2001), Uma Devi and Ganesan (2006), Biradar et al., (2007), Shivade et al., (2011) and Asif et al., (2019).

The inter correlation between yield contributing characters may affect the selection for component traits either in favorable or unfavorable direction. Hence, the knowledge on interrelationship between yield component traits may facilitate breeders to decide upon the intensity and direction of selection pressure to be given on related traits for the simultaneous improvement of these traits.

The estimates of correlation coefficients revealed only the relationship between yield components, but did not show the direct and indirect effects of different traits on yield. This is because the attributes which are in association do not exist by themselves, but are linked to other components. In order to get exact information of yield components on yield, the direct and indirect effects were investigated through path coefficient analysis which are presented in Table 3 and depicted in Fig 2. 
Table.1 List of blackgram genotypes included in the study

\begin{tabular}{|l|l|l|l|l|l|l|l|}
\hline S.No & Genotype & S.No & Genotype & S.No & Genotype & S.No & Genotype \\
\hline $\mathbf{1}$ & IC-260992 & $\mathbf{1 1}$ & IC-398956 & $\mathbf{2 1}$ & IC-426761 & $\mathbf{3 1}$ & IC-436535 \\
\hline $\mathbf{2}$ & IC-343812 & $\mathbf{1 2}$ & IC-398958 & $\mathbf{2 2}$ & IC-626763 & $\mathbf{3 2}$ & IC-436536 \\
\hline $\mathbf{3}$ & IC-343936 & $\mathbf{1 3}$ & IC-398970 & $\mathbf{2 3}$ & IC-426766 & $\mathbf{3 3}$ & IC-436545 \\
\hline $\mathbf{4}$ & IC-343942 & $\mathbf{1 4}$ & IC-398973 & $\mathbf{2 4}$ & IC-426768 & $\mathbf{3 4}$ & IC-436547 \\
\hline $\mathbf{5}$ & IC-343943 & $\mathbf{1 5}$ & IC-398380 & $\mathbf{2 5}$ & IC-426769 & $\mathbf{3 5}$ & IC-436559 \\
\hline $\mathbf{6}$ & IC-343947 & $\mathbf{1 6}$ & IC-398989 & $\mathbf{2 6}$ & IC-436508 & $\mathbf{3 6}$ & MBG-207 \\
\hline $\mathbf{7}$ & IC-343962 & $\mathbf{1 7}$ & IC-398998 & $\mathbf{2 7}$ & IC-436512 & $\mathbf{3 7}$ & LBG-752 \\
\hline $\mathbf{8}$ & IC-343967 & $\mathbf{1 8}$ & IC-426459 & $\mathbf{2 8}$ & IC-436517 & $\mathbf{3 8}$ & PU-31 \\
\hline $\mathbf{9}$ & IC-382811 & $\mathbf{1 9}$ & IC-426759 & $\mathbf{2 9}$ & IC-436524 & $\mathbf{3 9}$ & IPU-2-43 \\
\hline $\mathbf{1 0}$ & IC-384812 & $\mathbf{2 0}$ & IC-426760 & $\mathbf{3 0}$ & IC-436518 & & \\
\hline
\end{tabular}

Table.2 Correlation coefficient estimates for yield component traits in blackgram genotypes

\begin{tabular}{|c|c|c|c|c|c|c|c|c|}
\hline Character & $\begin{array}{c}\text { Days to } \\
50 \% \\
\text { flowering }\end{array}$ & $\begin{array}{l}\text { Days to } \\
\text { maturity }\end{array}$ & $\begin{array}{l}\text { Plant } \\
\text { height }\end{array}$ & $\begin{array}{c}\text { Number } \\
\text { of clusters } \\
\text { per plant }\end{array}$ & $\begin{array}{c}\text { Number } \\
\text { of pods } \\
\text { per plant }\end{array}$ & $\begin{array}{c}100 \text { seed } \\
\text { weight }\end{array}$ & $\begin{array}{c}\text { Seed yield } \\
\text { per plant }\end{array}$ & $\begin{array}{c}\text { Seed yield } \\
\text { (kg/ha) }\end{array}$ \\
\hline $\begin{array}{l}\text { Days to } 50 \% \\
\text { flowering }\end{array}$ & 1.0000 & $0.8014 * *$ & 0.0576 & -0.0295 & -0.0316 & 0.0698 & 0.0127 & 0.0126 \\
\hline Days to maturity & & 1.0000 & $0.1880^{*}$ & $0.1085^{*}$ & $0.1101^{*}$ & $0.3503 * *$ & $0.1489 *$ & $0.1499 *$ \\
\hline Plant height & & & 1.0000 & $0.4094 * *$ & $0.4129 * *$ & $0.4927 * *$ & $0.5635^{* *}$ & $0.5642 * *$ \\
\hline $\begin{array}{l}\text { Number of clusters } \\
\text { per plant }\end{array}$ & & & & 1.0000 & $0.8059 * *$ & $0.1140 *$ & $0.9034 * *$ & $0.9043 * *$ \\
\hline $\begin{array}{l}\text { Number of pods per } \\
\text { plant }\end{array}$ & & & & & 1.0000 & $0.1166^{*}$ & $0.9041 * *$ & $0.9051^{* *}$ \\
\hline 100 seed weight & & & & & & 1.0000 & $0.4552 * *$ & $0.4536 * *$ \\
\hline Seed yield per plant & & & & & & & 1.0000 & $0.4552 * *$ \\
\hline Seed yield (kg/ha) & & & & & & & & 1.0000 \\
\hline
\end{tabular}


Table.3 Path analysis estimates for yield component traits in blackgram genotypes

\begin{tabular}{|c|c|c|c|c|c|c|c|c|}
\hline Character & $\begin{array}{c}\text { Days to } \\
50 \% \\
\text { flowering }\end{array}$ & $\begin{array}{c}\text { Days to } \\
\text { maturity }\end{array}$ & $\begin{array}{c}\text { Plant } \\
\text { height }\end{array}$ & $\begin{array}{c}\text { Number } \\
\text { of clusters } \\
\text { per plant }\end{array}$ & $\begin{array}{c}\text { Number } \\
\text { of pods } \\
\text { per plant }\end{array}$ & $\begin{array}{c}100 \text { seed } \\
\text { weight }\end{array}$ & $\begin{array}{c}\text { Seed yield } \\
\text { per plant }\end{array}$ & $\begin{array}{c}\text { Seed yield } \\
(\mathrm{kg} / \mathrm{ha})\end{array}$ \\
\hline $\begin{array}{l}\text { Days to } 50 \% \\
\text { flowering }\end{array}$ & -0.0070 & -0.0056 & -0.0004 & 0.0002 & 0.0002 & -0.0005 & -0.0001 & 0.0126 \\
\hline $\begin{array}{l}\text { Days to } \\
\text { maturity }\end{array}$ & 0.0068 & 0.0084 & 0.0016 & 0.0009 & 0.0009 & 0.0030 & 0.0013 & 0.1499* \\
\hline Plant height & 0.0001 & 0.0004 & 0.0023 & 0.0009 & 0.0009 & 0.0098 & 0.0778 & $0.5642 * *$ \\
\hline $\begin{array}{l}\text { Number of } \\
\text { clusters per } \\
\text { plant }\end{array}$ & -0.0025 & 0.0093 & 0.0353 & 0.0861 & 0.0862 & 0.0098 & 0.0778 & $0.9043 * *$ \\
\hline $\begin{array}{l}\text { Number of pods } \\
\text { per plant }\end{array}$ & 0.0029 & -0.0101 & -0.0377 & -0.0915 & -0.0914 & -0.0107 & -0.0826 & $0.9051 * *$ \\
\hline 100 seed weight & -0.0005 & -0.0024 & -0.0033 & -0.0008 & -0.0008 & -0.0067 & -0.0031 & $0.4536 * *$ \\
\hline $\begin{array}{l}\text { Seed yield } \\
\text { (kg/ha) }\end{array}$ & 0.0128 & 0.1497 & 0.5665 & 0.9083 & 0.9090 & 0.4576 & 1.0054 & $0.4552 * *$ \\
\hline
\end{tabular}


Fig.1 Shaded correlation matrix for yield components in blackgram genotypes
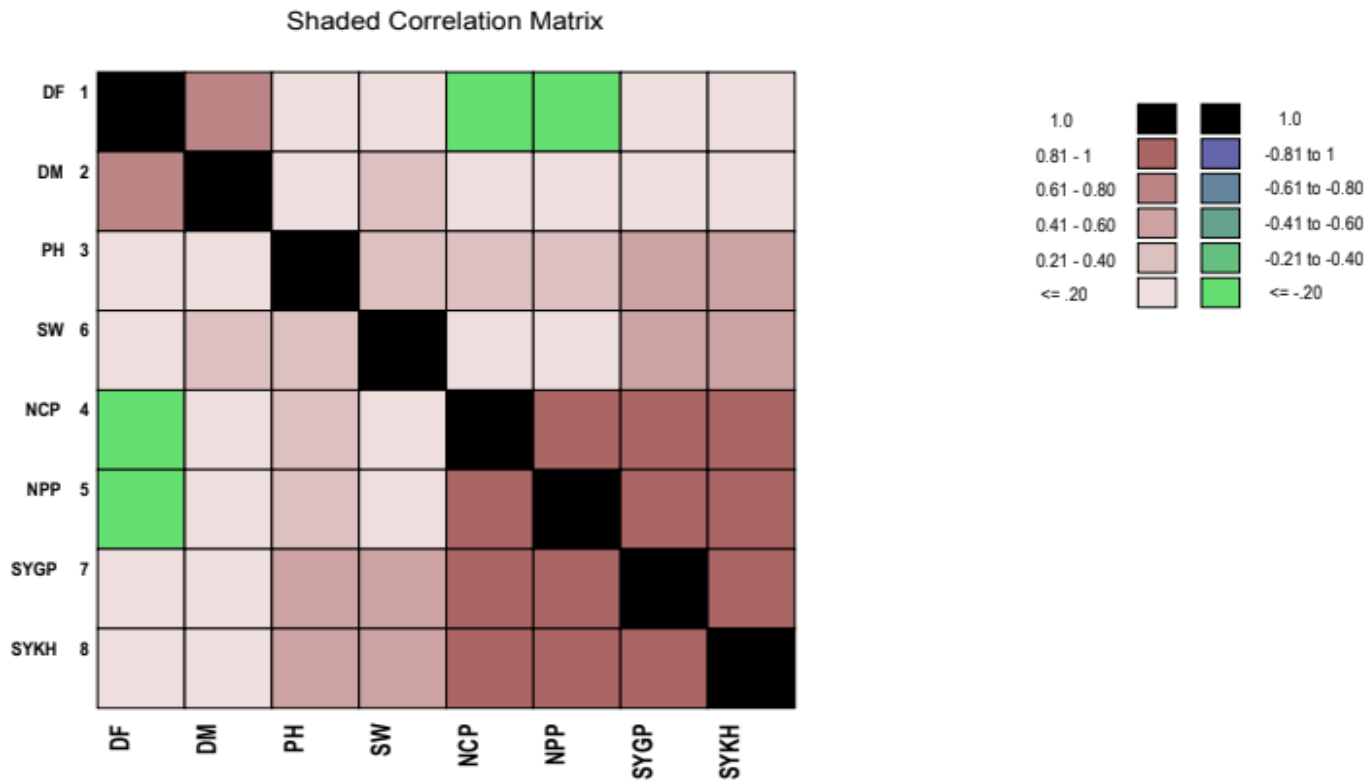

Fig.2 Genotypic path diagram of yield components with seed yield in blackgram genotypes

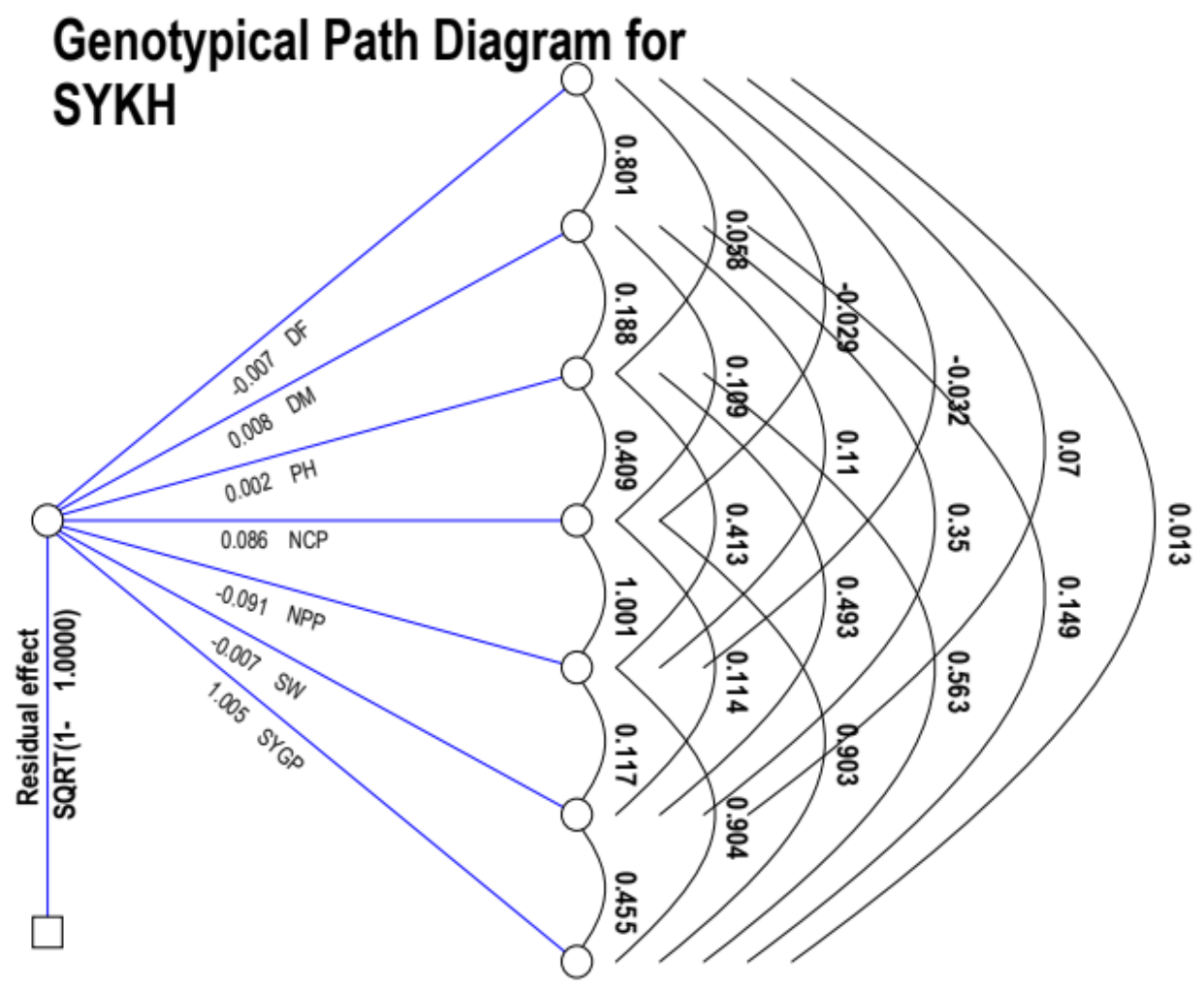


Days to maturity, plant height and number of clusters per plant showed positive direct effect coupled with positive indirect effects through number of pods per plant and seed 100 seed weight on seed yield per plant resulting in positive significant correlation with seed yield ( $\mathrm{kg} / \mathrm{ha})$.

From the facts, it is clear that all the yield component traits viz., days to maturity, plant height, number of clusters per plant, number of pods per plant,100 seed weight and seed yield per plant were inter correlated among themselves. Therefore, these traits are to be given priority selection to increase the seeding while selection is made for yielding. For path analysis it may be concluded that number of clusters per plant followed by 100 seed weight may be given due weightage during selection to increase the plant yield in the present material under study. These results are in accordance with the earlier findings of Singh et al., (2009), Reni et al., (2013), Muzibul Alom et al., (2014), Panigrahi et al., (2014), Mathivathana et al.,(2015) Blessy and Pavan (2018) and Mohanlal et al., (2018).

\section{References}

Al-Jibouri, H.A., Mullar P.A., and Rabinsion, H.F. (1958). Genetic and environmental variances and co-variances in an upland cotton cross of inter specific origin. Agronomy, 50: 633-636.

Asif Hadimani, CR Konda and Vikas Kulkarni 2019. Correlation and path coefficient analysis for yield and yield components in Blackgram (Vigna mungo (L.) Hepper. International Journal of Chemical Studies 2019; 7(1): 2240-2243.

Biradar, K. S. Salimath, P. M. and Ravikumar, R. L. (2007). Genetic studies in greengram and association analysis. Karnataka Journal of Agricultural Sciences; 20(4): 843-844.
Blessy V. and Pavan Naik B. 2018. Studies on Correlation and Path Analysis in Blackgram (Vigna mungo (L.) Hepper) Int.J.Curr.Microbiol.App.Sci ） 7(8): 1991-1997

Dewey, D.R. and Lu, K.H. (1959). A correlation and path coefficient analysis of components of crested wheat grass seed production. Agronomy Journal., 51:515-518.

Kaul, A. K. (1982). Pulses in Bangladesh. Bangladesh Agricultural research council (BARC). Farmgate, Dhaka. p.19

Mathivathana MK, Shunmugavalli N, Muthuswamy A, Vijulan HC. Correlation and path analysis in black gram. Agriculture Science Digest. 2015; 35(2): $158-160$

Mohanlal V. A., Saravanan, K. and Sabesan T. 2018. Studies on genetic correlation and path coefficient analysis of blackgram (Vigna mungo [L.] Hepper) genotypes under salinity. Journal Of Phytology 2018, 10: 09-11

Muzibul Alom KM, Rashid MH, Biswas M. Genetic variability, correlation and path analysis in mungbean (Vigna radiata (L.)). J Environ. Sci. and Natural Resources. 2014; 7(1):13.

Nagarjuna sagar, $\mathbf{M}$ and $M$. Reddy sekhar. 2001. Character association studies in blackgram (Vigna mungo [L] Hepper). Madras Agricultural Journal, 88(4-6): 222-224.

Panigrahi. K. K., A. Mohanty and B. Baisakh. 2014. Genetic divergence, variability and character association in landraces of blackgram (Vigna mungo [L] Hepper) from Odisha. J. Crop and Weed. 12;155-165.

Reni PY, Koteswara Rao Y, Satisha Y, Sateesh Babu J. Estimates of genetic parameters and path analysis in blackgram (Vigna mungo (L) Hepper). Int. J Pl. Ani. and Envi. Sci., 2013; 3(4):231-234. 
Shivade HA, Rewale AP, Patil SB. Correlation and path analysis for yield and yield components in blackgram (Vigna mungo (L) Hepper). Legume Research. 2011; 34(3):178-183.

Singh SK, Singh IP, Singh BB, Singh O. Correlation and path coefficient studies for yield and its components in mungbean (Vigna radiate (L)
Wiilczek). Legume Research. 2009; 32(3):180-185.

Umadevi, M. and Ganesan, N. M. (2006). Variability, correlation and path analysis for yield and yield components in blackgram [Vigna mungo (L.) Hepper]. Crop Research (Hisar); 31(2):253-257.

\section{How to cite this article:}

Sridhar, V., B. V. Vara Prasad, D. Shivani and Srinivasa Rao, S. 2020. Studies on Character Association and Path Coefficient Analysis for Yield Components in Blackgram (Vigna mungo (L). Hepper) Genotypes. Int.J.Curr.Microbiol.App.Sci. 9(01): 1824-1830.

doi: https://doi.org/10.20546/ijcmas.2020.901.204 